\title{
The prognostic value of carcinoembryonic antigen levels in blood and intraoperative pleural lavage fluid in non-small-cell lung cancer
}

\author{
Tevfik Ilker Akcam ${ }^{1}$, Ufuk Cagirici ${ }^{1}$, Ayse Gul Ergonul ${ }^{1}$, Ali Ozdil ${ }^{1}$, Onder Kavurmaci ${ }^{1}$, Kutsal Turhan $^{1}$, \\ Alpaslan Cakan ${ }^{1}$, Burcu Barutcuoglu ${ }^{2}$
}

${ }^{1}$ Department of Thoracic Surgery, School of Medicine, Ege University, Izmir, Turkey

${ }^{2}$ Department of Clinical Biochemistry, School of Medicine, Ege University, Izmir, Turkey

Kardiochirurgia i Torakochirurgia Polska 2017; 14 (2): 104-109

\begin{abstract}
Introduction: There is no specific marker for lung cancer, but, in some lung cancer types, carcinoembryonic antigen (CEA) can reach high levels in the blood and pleural fluid.

Aim: This study investigated the relationship of CEA levels in blood $\left(C E A_{B}\right)$ and intraoperative pleural lavage fluid $\left(C E A_{P}\right)$ in non-small-cell lung cancer (NSCLC) with the type, stage, and extent of lung cancer.

Material and methods: A total of 50 patients, who underwent surgery at our clinic due to NSCLC (group I) or benign lung pathology (group II), were assessed. For this prospectively designed study, 25 consecutive patients were included in each group, and their $\mathrm{CEA}_{\mathrm{B}}$ and $\mathrm{CEA}_{\mathrm{p}}$ levels were investigated.

Results: When the levels of $\mathrm{CEA}_{p}$ were compared, the average value of group I $(1.35 \mathrm{ng} / \mathrm{ml})$ was significantly higher than the average value of group II $(0.04 \mathrm{ng} / \mathrm{ml})(p=0.027)$. When CEA levels were examined separately, and average values were taken according to surgical pathology results, both $C_{E A}$ and $\mathrm{CEA}_{p}$ levels of adenocarcinoma patients were found to be higher than those of the other groups. This difference was only significant for the level of $\operatorname{CEA}_{\mathrm{p}}(p=0.026)$.

Conclusions: Although the average $C E A_{B}$ levels of patients with adenocarcinoma were higher than those of patients with other histopathological types, this difference was not statistically significant. However, we found that $C \mathrm{~A}_{\mathrm{p}}$ levels were significantly higher in patients with adenocarcinoma. These results have led us to consider that $C_{E A_{p}}$ elevation is a more sensitive marker than the elevation of $C E A_{B}$.

Key words: carcinoembryonic antigen, non-small-cell lung cancer, pleural lavage.
\end{abstract}

\section{Introduction}

Lung cancer is the most common type of cancer, resulting in the death of men and women in Turkey and throughout the world. Globally, each year about one million men and 400 thousand women develop lung cancer, and 1.2 mil-

\section{Streszczenie}

Wstęp: Nie istnieje, co prawda, specyficzny marker dla raka płuc, jednak przy niektórych rodzajach raka płuc antygen rakowo-płodowy (CEA) może osiągać wysokie wartości w krwi oraz w płynie opłucnowym.

Cel: Analiza związków stężenia CEA w krwi $\left(C_{B} A_{B}\right)$ oraz w płynie ze śródoperacyjnego płukania opłucnej $\left(C E A_{p}\right)$ w niedrobnokomórkowym raku płuca (NSCLC) z rodzajem, stadium oraz rozległością raka płuca.

Materiat i metody: Przebadano grupę 50 pacjentów poddanych zabiegom chirurgicznym w naszym ośrodku z powodu NSCLC (grupa I) lub łagodnych zmian płucnych (grupa II). Dla celów przedstawionego poniżej prospektywnego badania każda z grup składała się z 25 kolejnych pacjentów; oznaczono stężenia antygenu w krwi i w płynie opłucnowym.

Wyniki: Porównanie stężeń CEA $A_{p}$ wykazało, że średnia ich wartość w grupie I $(1,35 \mathrm{ng} / \mathrm{ml})$ była znacząco wyższa niż średnia wartość w grupie II $(0,04 \mathrm{ng} / \mathrm{ml})(p=0,027)$. Kiedy stężenia CEA oznaczono odrębnie, a średnie wartości przeanalizowano w stosunku do wyników badań patomorfologicznych, okazało się, że wartości zarówno $C_{E} A_{B}$, jak i CEA u pacjentów z rakiem gruczołowym były wyższe niż w pozostałych grupach. Różnica ta była istotna statystycznie jedynie w przypadku CEA $(p=0,026)$.

Wnioski: Średnie stężenie $C_{E A}$ u pacjentów z rakiem gruczołowym było większe niż u pacjentów z innymi typami histopatologicznymi; różnica ta nie była jednak istotna statystycznie. Niemniej stężenie CEA $A_{p} u$ tych pacjentów było istotnie większe. Wyniki sugerują, że CEA $A_{p}$ może być czulszym markerem niż CEA ${ }_{B}$. Słowa kluczowe: antygen rakowo-płodowy, niedrobnokomórkowy rak płuca, płukanie opłucnej.

lion people die as a result. This number represents $17 \%$ of cancer-related deaths; the number of lung cancer deaths is higher than the combined number of patients who die due to colon, breast, and prostate cancer [1].

Tumor markers are produced by related tumors or tissues at supraphysiological levels; they can be found in hor-

Address for correspondence: Tevfik Ilker Akçam MD, Department of Thoracic Surgery, Faculty of Medicine, Ege University, Izmir, Turkey, phone: +90 5386062581, fax: +90 2323904681, e-mail: tevfikilkerakcam@hotmail.com

Received: 17.02.2017, accepted: 20.04.2017. 
mone, enzyme, metabolite, immunoglobulin, and protein structures and can be measured quantitatively in the tissue, blood, or other body fluids of patients with the use of biochemical or immunochemical methods. Specific tumor markers can be identified according to the type and prevalence of the tumor. Tumor markers are used for risk identification, early cancer screening, and confirmation of diagnosis; they are also used to determine prognosis, select optimal therapy, and predict disease recurrence or progression during the follow-up period. They can thus provide insights into many aspects of the disease [2].

There is no specific marker for lung cancer in the strictest sense; notwithstanding, an oncofetal antigen known as carcinoembryonic antigen (CEA) can reach high levels in some types of lung cancer, even though it is not specific to lung cancer $[3,4]$. While it has been reported that various levels of this antigen can be detected in the pleura in the presence of malignancy, there is no consensus on the subject $[5,6]$.

\section{Aim}

This study investigated the relationship of CEA levels in blood $\left(C E A_{B}\right)$ and intraoperative pleural lavage fluid $\left(C E A_{p}\right)$ in non-small-cell lung cancer (NSCLC) patients with the type, stage, and extent of lung cancer; it also examined the differences in CEA levels between malignant patients and benign patients. Accordingly, the usefulness of CEA levels as a guide in the treatment of lung cancer was evaluated.

\section{Material and methods}

A total of 50 patients were assessed between December 2011 and October 2012; all subjects were selected from among the patients who were admitted to our clinic and underwent surgery due to non-small-cell lung carcinoma (NSCLC) (group I - study group) or benign lung pathology (group II - control group). For this prospectively designed study, 25 consecutive patients were included in each group. The levels of $C E A_{B}$ and $C E A_{P}$ were investigated in a total of 50 patients. Patients undergoing videothoracoscopic surgery who had additional malignancies other than NSCLC were not included in this study.

The patients in both groups were evaluated using blood biochemistry tests, electrocardiography, respiratory function tests, arterial blood gas tests, PA and lateral chest $X$-ray, and computed tomography. When needed, positron emission tomography (PET) and magnetic resonance imaging (MRI) examinations were performed. To obtain a diagnosis, one or more of the following methods were applied: sputum cytology, transthoracic fine needle aspiration (FNA), bronchoscopic intervention (lavage, brushing, biopsy). Mediastinoscopic lymph node biopsies were conducted when required. The classification of patients in group I was made in accordance with the international lung cancer classification accepted in 2009 by the International Association for the Study of Lung Cancer (IASLC). Histopathological typing was in accordance with the World Health Organization classification from $2004[7,8]$.
After thoracotomy, lavage of the pleural cavity was conducted with $100 \mathrm{ml}$ of saline fluid without any manipulation. Measurement of CEA in lavage fluid was done using the electrochemiluminescence immunoassay (ECLIA) method (Modular Analytics, E170, Roche Diagnostics GmbH, D-68298 Mannheim, Germany). The measuring range was determined to be $0.2-1000 \mathrm{ng} / \mathrm{ml}$, and the lower limit was $0.2 \mathrm{ng} / \mathrm{ml}$.

\section{Statistical analysis}

For the comparison of blood and fluid CEA levels between the two groups, the Mann-Whitney $U$ test was used. To calculate the relationships between CEA levels and age, gender, smoking history, comorbidity, stage of the disease, and surgical pathology, the $\chi^{2}$ test, Fisher's exact test and Kruskal-Wallis analysis were used. Values of $p<0.05$ were considered significant in all tests.

\section{Results}

The average age of group I (study group) was 59.90 \pm 7.90 years (range: $33-73$ ), and only 1 patient was female. Three (12\%) patients were under the age of 55 . All patients underwent anatomic lung resection; in 14 (56\%) of these patients, the lesion was on the right side. Histopathological examinations revealed the following conditions: 11 squamous cell carcinomas (44\%), 10 adenocarcinomas (40\%), 1 carcinoid tumor (0.4\%), 1 neuroendocrine tumor, 1 mucoepidermoid carcinoma, and 1 pulmonary blastoma. The $\mathrm{CEA}_{B}$ was at measurable levels in all cases, while the CEA level of 15 patients could not be measured as it was under $0.2 \mathrm{ng} / \mathrm{ml}$. The clinical stages of the patients were as follows: IA: six, IB: nine, IIA: three, IIB: one, IIIA: six. Altogether, 15 (60\%) patients had comorbidities accompanying the lung cancer, which included: hypertension (HT), chronic obstructive pulmonary disease (COPD), diabetes mellitus (DM), coronary artery disease (CAD), and cerebrovascular accident (CVA). Only 4 (16\%) patients in group I did not have a history of smoking. No early postoperative mortality was observed, while morbidity was noted in 5 (20\%) patients: chylothorax and arrhythmia in 2 patients each and pneumonia in 1 patient (Tab. I).

The average age of group II (control group) was 44.04 \pm 12.89 years (range: $24-62$ ), and it included 13 (52\%) male and $12(48 \%)$ female patients. Diagnoses of the patients in this group were as follows: 7 hydatid cysts, 6 bronchiectases, 4 mediastinal cysts, 2 organizing pneumonias, 2 solitary fibrous tumors, 2 bullous lung diseases, 1 fibrous rib dysplasia, and 1 hamartoma. It was impossible to measure the $C_{C A}$ level in only 1 patient; in turn, the CEA level was measurable (over $0.2 \mathrm{ng} / \mathrm{ml}$ ) in only 4 cases. In this group, 12 (48\%) patients did not have a smoking history. There was no postoperative mortality; morbidity developed in $5(20 \%)$ patients: hemorrhage requiring blood and blood product replacement in 4 patients and pneumothorax in 1 patient (Tab. I). Patients in both groups were examined in two categories: 55 years of age or older and under 55 years. In group I, there were only three patients under 
Tab. I. Demographic data

\begin{tabular}{|c|c|c|c|c|}
\hline Parameter & & Group I & Group II & $P$-value \\
\hline \multirow[t]{2}{*}{ Age } & $<55$ & 3 (12\%) & $18(72 \%)$ & $<0.01$ \\
\hline & $\geq 55$ & $22(88 \%)$ & 7 (28\%) & \\
\hline \multirow[t]{2}{*}{ Sex } & Male & $24(96 \%)$ & $13(52 \%)$ & $<0.01$ \\
\hline & Female & $1(4 \%)$ & $12(48 \%)$ & \\
\hline \multirow[t]{2}{*}{ Smoking } & + & $21(84 \%)$ & $13(52 \%)$ & 0.032 \\
\hline & - & $4(16 \%)$ & $12(48 \%)$ & \\
\hline \multirow[t]{6}{*}{ Complication } & Chylothorax & 2 & - & \\
\hline & Arrhythmia & 2 & - & \\
\hline & Pneumonia & 1 & - & \\
\hline & $\begin{array}{l}\text { Blood product } \\
\text { replacement }\end{array}$ & - & 4 & \\
\hline & Pneumothorax & - & 1 & \\
\hline & Total & 5 & 5 & 0.948 \\
\hline \multirow[t]{8}{*}{ Histology } & $\mathrm{AC}$ & 10 & - & \\
\hline & SCC & 11 & - & \\
\hline & Other malign & 4 & - & \\
\hline & Hydatid cyst & - & 7 & \\
\hline & Bronchiectasis & - & 6 & \\
\hline & Mediastinal cyst & - & 4 & \\
\hline & Bullous emphysema & - & 2 & \\
\hline & Other benign & - & 6 & \\
\hline \multirow[t]{5}{*}{ Stage } & $1-A$ & 6 & - & \\
\hline & $1-B$ & 9 & - & \\
\hline & $2-A$ & 3 & - & \\
\hline & $2-B$ & 1 & - & \\
\hline & $3-A$ & 6 & - & \\
\hline \multirow{7}{*}{$\begin{array}{l}\text { Concomitant } \\
\text { diseases }\end{array}$} & Hypertension & 5 & 7 & \\
\hline & COPD & 5 & 2 & \\
\hline & CAD & 2 & - & \\
\hline & DM & 2 & 3 & \\
\hline & CVE & 1 & - & \\
\hline & Asthma & - & 3 & \\
\hline & Total & 15 & 15 & 0.985 \\
\hline
\end{tabular}

AC - adenocarcinoma, SCC - squamous cell carcinoma, COPD - chronic obstructive pulmonary disease, CAD - coronary artery disease, DM - diabetes mellitus, CVE - central vascular event.

55 years, while group II included 18 patients under the age of 55. Most of the group II patients in whom malignant disease was established were over 55 years of age. As lung malignancies can be seen more often in older age groups, this situation was consistent with the literature.

\section{Average CEA levels}

When $C_{B A}$ levels were evaluated, the lowest value in group I was $0.77 \mathrm{ng} / \mathrm{ml}$, and the highest value was $139.3 \mathrm{ng}$ / $\mathrm{ml}$ (average: $4.12 \mathrm{ng} / \mathrm{dl}$ ). In turn, the lowest value in group II was $<0.2 \mathrm{ng} / \mathrm{ml}$, and the highest value was measured as 
Tab. II. CEA levels in blood and pleural lavage fluid

\begin{tabular}{|c|c|c|c|c|c|c|c|}
\hline Variable & Group & $N$ & Average & Std. deviation & Min. & Max. & $P$-value \\
\hline \multirow[t]{2}{*}{$\mathrm{CEA}_{\mathrm{B}}$} & I & 25 & 14.13 & 34.51 & 0.77 & 139.30 & \multirow{2}{*}{0.001} \\
\hline & II & 25 & 1.70 & 0.92 & 0.54 & 3.42 & \\
\hline \multirow[t]{2}{*}{$\mathrm{CEA}_{p}$} & I & 25 & 1.35 & 3.17 & 0 & 14.35 & \multirow{2}{*}{0.027} \\
\hline & $\|$ & 25 & 0.04 & 0.10 & 0 & 0.38 & \\
\hline
\end{tabular}

$\mathrm{CEA}_{B}$ - blood, CEAp - pleural lavage fluid.

$3.42 \mathrm{ng} / \mathrm{ml}$ (average: $1.69 \mathrm{ng} / \mathrm{ml}$ ). The upper limit of normal CEA $A_{B}$ value was defined as $5 \mathrm{ng} / \mathrm{ml}$ : the average $C E A_{B}$ values in both group I and group II were under this limit. The intergroup difference between the average values of $\mathrm{CEA}_{\mathrm{B}}$ was statistically significant $(p<0.05)$. When CEA $\mathrm{A}_{\mathrm{p}}$ levels were compared, the average value in group I was found to be higher than that of group II, and this difference was statistically significant ( $p=0.027)$ (Tab. II).

\section{Surgical pathology - CEA level}

The histopathological diagnosis of patients in group I was studied under six headings. As pathologies other than adenocarcinoma and squamous cell carcinoma were very rare, they were collected under the common heading 'other'. When CEA levels were examined separately and average values were considered with regard to surgical pathology results, both the $C E A_{B}$ and $C E A_{P}$ levels were found to be higher in patients diagnosed with adenocarcinoma than in the other groups. Statistical analysis demonstrated that this difference was only significant for the level of $C E A_{P}$ $(p=0.026)(T a b . I I)$.

\section{Stage - CEA level}

When the disease stages were assessed, the highest average values of $C_{B} A_{B}$ and $C E A_{p}$ were seen in stage III patients. But when this elevation was compared with patients in other stages, statistical significance was not detected. When stage I was compared with the other stages, CEA levels were shown to be lower in stage I than in more advanced stages, but this was also not statistically significant.

\section{Discussion}

Since the importance of early stage cancer detection cancer was understood, many studies have been conducted in the search for a simple technique to facilitate early detection of all types of cancer, including lung cancer. Tumor marker analysis is straightforward and particularly useful in this context. After carcinoembryonic antigen (CEA) was first defined in 1965, many studies were published on the value of this marker for the diagnosis of various organ cancers, including lung cancer. Based on these studies, it has been established that CEA cannot be used alone for lung cancer detection, but it can be beneficial for guidance $[9,10]$. Larger quantities of CEA are released in advanced lung cancer, and it has been asserted that, in lung cancer, CEA can be a serum marker with staging potential [11]. In various clinical studies, lower CEA levels were detected in
Tab. III. CEA level relation in subtypes of group I cases

\begin{tabular}{|c|c|c|c|}
\hline Parameter & & $\begin{array}{c}\mathrm{CEA}_{\mathrm{B}} \\
\text { (min.-max.) }\end{array}$ & $\begin{array}{c}\text { CEA }_{p} \\
\text { (min.-max.) }\end{array}$ \\
\hline \multirow[t]{3}{*}{ Age } & $<55$ & $\begin{array}{c}39.64 \\
(0.77-116.20)\end{array}$ & $\begin{array}{c}4.88 \\
(0-14.35) \\
\end{array}$ \\
\hline & $\geq 55$ & $\begin{array}{c}10.64 \\
(1.21-139.30)\end{array}$ & $\begin{array}{c}0.86 \\
(0-5.77) \\
\end{array}$ \\
\hline & $P$-value & 0.558 & 0.257 \\
\hline \multirow[t]{3}{*}{ Smoking } & + & $\begin{array}{c}10.46 \\
(0.77-139.30)\end{array}$ & $\begin{array}{c}0.92 \\
(0-5.77)\end{array}$ \\
\hline & - & $\begin{array}{c}33.37 \\
(1.87-116.20)\end{array}$ & $\begin{array}{c}3.58 \\
(0-14.35)\end{array}$ \\
\hline & $P$-value & 0.767 & 0.802 \\
\hline \multirow[t]{4}{*}{ Histology } & $A C$ & $\begin{array}{c}29.70 \\
(1.21-139.30)\end{array}$ & $\begin{array}{c}2.99 \\
(0-14.35)\end{array}$ \\
\hline & SCC & $\begin{array}{c}4.26 \\
(0.77-13.50)\end{array}$ & $\begin{array}{c}0.31 \\
(0-3.14)\end{array}$ \\
\hline & Other malign & $\begin{array}{c}2.31 \\
(1.97-2.82)\end{array}$ & $\begin{array}{c}0.77 \\
(0-1.34) \\
\end{array}$ \\
\hline & $P$-value & 0.176 & 0.026 \\
\hline \multirow[t]{3}{*}{ Stage } & $I A+I B$ & $\begin{array}{c}3.61 \\
(0.77-11.16)\end{array}$ & $\begin{array}{c}0.41 \\
(0-4.54)\end{array}$ \\
\hline & $\|A+\| B+\| A$ & $\begin{array}{c}29.89 \\
(1.56-139.30) \\
\end{array}$ & $\begin{array}{c}2.74 \\
(0-14.35) \\
\end{array}$ \\
\hline & $P$-value & 0.149 & 0.210 \\
\hline \multirow[t]{3}{*}{$\begin{array}{l}\text { Concomitant } \\
\text { diseases }\end{array}$} & + & $\begin{array}{c}13.32 \\
(1.56-139.30)\end{array}$ & $\begin{array}{c}0.75 \\
(0-5.77)\end{array}$ \\
\hline & - & $\begin{array}{c}15.32 \\
(0.77-116.20)\end{array}$ & $\begin{array}{c}2.24 \\
(0-14.35)\end{array}$ \\
\hline & $P$-value & 0.739 & 0.316 \\
\hline
\end{tabular}

$\mathrm{CEA}_{B}$ - blood, CEAp - pleural lavage fluid, AC - adenocarcinoma, SCC - squamous cell carcinoma.

asymptomatic patients in comparison with symptomatic patients [12]. However, since the marker can be detected at high levels in smokers and COPD patients, as well as cancer patients, Dent et al. reported that CEA was not suitable for tumor screening [13].

Although it is not a specific marker for lung cancer, studies have been conducted to compare blood and pleural fluid CEA levels in different types of lung cancer and at different stages. Preoperative CEA elevation was found to be a poor prognostic sign $[5,14,15]$. Rubbins et al. [16] asserted that serum CEA levels could provide additional prognostic information independent of age, stage, histological type, and tumor size. Their statistical analysis demonstrated that elevated preoperative serum levels of CEA were associated with significantly decreased postoperative survival time. The study also reported that serum CEA levels provided 
information additional to that obtained with conventional methods of preoperative lung cancer staging.

Shoji et al. [17] reported a positive correlation between serum CEA elevation and EGFR mutation and recurrence. Stokes et al. [18] suggested that routine CEA measurements before surgery could define the small patient group with metastatic disease, and that general research in this patient group should be conducted. Furthermore, their study noted early metastasis in all patients with high preoperative serum CEA levels. Salgia et al. [3] investigated the role of CA 125 and CEA in NSCLC. The researchers compared patients with early stage disease and patients with unresectable or metastatic disease, observing that the CA 125 and CEA levels were lower in the early stage group and that the serum CEA level was higher in patients with adenocarcinoma. They also noted that the CEA and CA 125 levels were decreased after chemotherapy. With these findings, they concluded that CA 125 and CEA levels could be a marker for disease progression and response to treatment in lung cancer patients.

In our study, the detected level of $\mathrm{CEA}_{\mathrm{p}}$ was statistically higher in cases of adenocarcinoma, and the level of $C E A_{B}$ was higher in patients with lung adenocarcinoma, but statistical significance was not achieved. In similar studies conducted to investigate this subject, $\mathrm{CEA}_{B}$ was described as the most sensitive (75.7\%) tumor marker for the diagnosis of adenocarcinoma; it was also determined that the elevation of this marker was more pronounced in adenocarcinoma in comparison with other lung cancer types [3, 4, 16]. Tomita et al. [19] published a comprehensive study assessing patients with adenocarcinoma; they reported that there was no correlation between positive pleural cytology and blood CEA levels, but there was a correlation between $\mathrm{CEA}_{\mathrm{B}}$ and $\mathrm{CEA}_{\mathrm{p}}$ levels. Moreover, correlations were detected between the stage of the disease and the increase of the CEA level. The authors emphasized that the level of CEA could be a prognostic indicator in patients with N1-2 lymph node involvement. The levels of $C E A_{P}$ and $C E A_{B}$ in our study were high in patients with more advanced stages and N2 involvement, but statistical significance was not detected.

Takamochi et al. demonstrated that NSCLC patients with a tumor diameter of less than $20 \mathrm{~mm}$ had significantly lower CEA levels, but there was no directly proportional elevation with the increase of tumor diameter. On the other hand, the researchers reported that $C E A_{B}$ levels are more valuable than lymph node size on $\mathrm{CT}$ when determining mediastinal $\mathrm{N} 2$ involvement. In the same study, pN2 was detected in $33 \%$ of the patients whose $C_{\text {EA }}$ level exceeded $5 \mathrm{ng} / \mathrm{dl}$ and whose tumor diameter exceeded $20 \mathrm{~mm}$; based on these data, mediastinoscopy was recommended for patients with high CEA levels and tumor diameter of $20 \mathrm{~mm}$ or more [20]. A similar study demonstrated that $\mathrm{CN} 2$, tumor size, adenocarcinoma histology, and high $\mathrm{CEA}_{\mathrm{B}}$ level are markers of $\mathrm{pN2}$ which can be used to preoperatively determine the mediastinal spread of the disease in lung cancer patients in whom N2 disease was not detected with thoracic CT. The authors concluded that mediastinoscopy is unnecessary in $80 \%$ of patients with clinical N0-1 disease [21].

Most studies on the value of CEA for the diagnosis of lung cancer analyzed the blood levels of this marker. In recent years, there were also studies that investigated $C \mathrm{~A}_{p}$ levels and compared them with lavage cytology [6]. We believe that results with high statistical significance can be achieved by increasing the number of studies and conducting a meta-analysis.

It is well known that $C A_{B}$ levels are high in patients with adenocarcinoma. Although the average $C_{B} A_{B}$ level in our study was higher in adenocarcinoma patients than in patients with other histopathological types, this difference was not statistically significant. In turn, the CEA $A_{p}$ levels were found to be significantly higher in patients with adenocarcinoma. These findings have led us to consider that CEA may be a more sensitive marker than $C_{P} A_{B}$. Furthermore, they have shown us that $C E A_{P}$ levels should be examined even in patients with low $C E A_{B}$ levels. Given the increasing proportion of adenocarcinoma in the pathological types of lung cancer, we think that the level of CEA in blood and/or pleural lavage fluid could be used to guide the diagnosis, staging, postoperative treatment planning, and determination of prognosis in adenocarcinoma. Therefore, we believe that a multicenter prospective study should be conducted on the subject.

\section{Ethical board approval}

The study protocol has been approved by the Institutional Review Board of Ege University Medical School (decision no. 1462/369), and the study has been performed in accordance with the ethics standards laid down in the 1964 Declaration of Helsinki and its later amendments.

\section{Informed consent}

Informed consent was obtained from each participant included in the study.

\section{Disclosure}

Authors report no conflict of interest.

\section{References}

1. Pirozynski M. Historical review: 100 years of lung cancer. Respir Med 2006; 100: 2073-2084.

2. Butch AW, Pappas AA. Tumor markers. In: Tretz Textbook of Clinical Biochomistry. Burtis CA, Ashwood ER (eds). $2^{\text {nd }}$ ed. Saunders, Philadelphia 1994; 483-500.

3. Salgia R, Harpole D, Herndon JE, Pisick E, Elias A, Skarin AT. Role of serum tumor markers CA 125 and CEA in non-small cell lung cancer. Anticancer Res 2001; 21: 1241-1246.

4. Tomita M, Matsuzaki Y, Edagawa M, Shimizu T, Hara M, Onitsuka T. Prognostic significance of preoperative serum carcinoembryonic antigen level in lung adenocarcinoma but not squamous cell carcinoma. Ann Thorac Cardiovasc Surg 2004; 10: 76-80

5. Tomita M, Shimizu T, Ayabe T, Yonei A, Onitsuka T. Carcinoembryonic antigen level in serum and pleural lavage fluid in non-small cell lung cancer. Thorac Cardiovasc Surg 2010; 58: 350-353.

6. Tsutani Y, Yamashita Y, Misumi K, Ikeda T, Miyata Y, Okada M. Non-smallcell lung cancer prognosis using carcinoembryonic antigen levels in pleural lavage fluid. Eur J Cardiothorac Surg 2012; 42: 96-101. 
7. Travis WD, Brambilla E, Müller-Hermelink HK, Harris CC. World Health Organization Classfication of Tumors. Tumors of the Lung, Pleura, Thymus and Heart. IARC Press, Lyon 2004.

8. International Union Aganist Cancer. TNM classification of malignant tumors. Willey-Liss $5^{\text {th }}$ ed, New York 1997; 93-97.

9. Watanabe R, Takiguchi Y, Kuriyama T. Serum tumor markers for pirmary lung carcinoma. Nihon Rinsho 2000; 58: 1070-1073.

10. Buccheri GF, Ferrigno D, Sartoris AM, Violante B, Vola F, Curcio A. Tumor markers in bronchogenic carcinoma. Cancer 1987; 60: 42-50.

11. Vińolas N, Molina R, Galán MC, Casas F, Callejas MA, Filella X, Grau JJ, Ballesta AM, Estape J. Tumor markers in response monitoring and prognosis of nonsmall cell lung cancer preliminary report. Anticancer Res 1998; 18: 631-634.

12. Fletcher MD. Carcinoembryonic antigen. Ann Intern Med 1986; 104: 66-73.

13. Dent PB, Mcculloch PB, Wesley-James O, Maclaren R, Muirhead W, Dunnet CW. Measurement of carcinoembryonic antigen in patients with bronchogenic carcinoma. Cancer 1978; 42: 1484-1491.

14. Takahashi N, Suzuki K, Takamochi K, Oh S. Prognosis of surgically resected lung cancer with extremely high preoperative serum carcinoembryonic antigen level. Thorac Cardiovasc Surg 2011; 59: 699-704.

15. Okada M, Nishio W, Sakamoto T, Uchino K, Yuki T, Nakagawa A, Tsubota N Prognostic significance of perioperative serum carcinoembryonic antigen in non-small cell lung cancer: analysis of 1000 consecutive resections for clinical stage I disease. Ann Thorac Surg 2004; 78: 216-221.
16. Rubbins JB, Dunitz J, Rubins HB, Maddaus MA, Niewoehner DE. Serum carcinoembryonic antigen as an adjunct to preoperative staging of lung cancer. Thorac Cardiovasc Surg 1998; 116: 412-416.

17. Shoji F, Yoshino I, Yano T, Kometani T, Ohba T, Kouso H, Takenaka T, Miura N, Okazaki H, Maehara Y. Serum carcinoembryonic antigen level is associated with epidermal growth factor receptor mutations in recurrent lung adenocarcinomas. Cancer 2007; 110: 2793-2798.

18. Stokes TC, Stevens JF, Logn P, Lockey E, Miller AL. Preoperative carcinoem bryonic antigen and survival after resection of lung cancer. $\mathrm{Br} J$ Dis Chest 1980; 74: 390-394.

19. Tomita M, Shimizu T, Matsuzaki Y, Hara M, Ayabe T, Onitsuka T. Prognostic significance of carcinoembryonic antigen level in pleural lavage fluid for patients with lung adenocarcinoma. Ann Thorac Surg 2005; 80: 276-281.

20. Takamochi K, Yoshida J, Nishimura M, Yokose T, Sasaki S, Nishiwaki Y, Suzuki K, Nagai K. Prognosis and histologic features of small pulmonary adenocarcinoma based on serum carcinoembryonic antigen level and computed tomographic findings. Eur J Cardiothorac Surg 2004; 25: 877-883.

21. Suzuki K, Nagai K, Yoshida J, Nishimura M, Takahashi K, Nishiwaki Y. Clinical predictors of $\mathrm{N} 2$ disease in the setting of a negative computed tomographic scan in patients with lung cancer. J Thorac Cardiovasc Surg 1999; 117: 593-598. 